\title{
A PROFILE OF ELECTROLYTES IN THE CARTILAGINOUS PLATE OF GROWING RIBS *
}

\author{
By D. S. HOWELL, $\dagger$ E. DELCHAMPS, W. RIEMER $\ddagger$ AND I. KIEM \\ (From the Arthritis Section, Department of Medicine and Department of Pathology, Uni- \\ versity of Miami School of Medicine, Jackson Memorial Hospital, \\ Miami, Fla.)
}

(Submitted for publication July 1, 1959; accepted February 26, 1960)

In the past little attention has been paid to the histological zonal composition of cartilage used for quantitative electrolytic analysis (1). In the ribs and long bones the major fraction of the cartilage available is composed histologically of the resting cell zone (Figure 1), yet the adjacent proliferating and hypertrophic cell zones-narrow layers of cells at the site of new longitudinal bone growth-are more active metabolically (2), and may play an important role in new bone production. Fortunately, the unique architecture of the costochondral junction in mammals enables the separation of these component histological zones. Whereas epiphyseal cartilages of long bones are concave and therefore difficult to section, ribs terminate anteriorly in a flat plate of cartilage, within which the maturing chondrocytes are arranged in approximately parallel zones (Figure 1, A and B). In 1949 Follis divided this tissue by cross-sectional slicing and demonstrated increased alkaline phosphatase activity of the layers adjacent to the bone marrow surface in both human and animal subjects (3). However, with only single slices available for analysis, the method was inadequate for comprehensive electrolyte studies. The current report describes a method for pooling cartilaginous, cross-sectional slices according to their histological zonal constituents and relates cartilage maturation to electrolytic content. Particular attention is directed to the regional content of sodium and calcium with evidence for an increasing storage of calcium by matrix macroanions adjacent to the zone of provisional calcification.

* Supported by Grant A1155 from the National Institute of Arthritis and Metabolic Diseases, Bethesda, Md.

$\dagger$ Assistant Professor of Medicine, Scholar of the John and Mary Markle Foundation.

$\ddagger$ Instructor in pathology.

\section{MATERIALS AND METHODS}

Costal cartilage from 6-week-old calves ${ }^{1}$ was obtained within 2 hours of sacrifice at a local abattoir. After removal of fat, muscle and perichondrium, cartilage was manually separated from the ribs and quickly frozen in an isopentane bath cooled with liquid nitrogen. Each frozen costochondral junction was set in a microtome with a razor attachment as described by Follis (3). Six consecutive cross-sectional slices were made under freezing conditions, with the cartilage so oriented that the first slice included the zones of provisional calcification, hypertrophic and proliferating cells, and last, the resting cell zone (Figure 1, A through F). Cartilage from the second through the sixth rib of a cage formed a unit. Eleven such units were cross-sectioned and all first slices pooled, and so on, for 6 slices. Each crosssectional slice was divided sagittally; half of the tissue was retained for chemical analysis, the other half for histological study. Therefore, 660 slices from 11 calf-rib cages were analyzed for histological composition. Tissues were fixed for 24 hours in 10 per cent neutral formalin, and after conventional processing, were sectioned coronally at $6 \mu$ thickness, mounted, and stained by a Harris hematoxylin-eosin sequence.

Each slice contained 2 or more of the 5 histological zones described above. Thus, correlation of histological with chemical analyses required an estimation of the average relative volume occupied by any histological zone in each slice. Each costochondral junction resembled an elliptical cylinder with a volume equal to $\pi \mathrm{abH}$, where $\mathrm{a}$ and $\mathrm{b}$ are the lengths of the semi-major and semi-minor cross-sectional axes and $\mathrm{H}$ represents the width of the cartilage in a rib's longitudinal axis (Figure 1B). In a given slice, $a$ and $b$ are approximately unaltered at all depths so that changes of volume are directly proportional to $\mathrm{H}$. Each zone was considered a cross-sectional subdivision of the cylinder of width $h_{1}, h_{2} \ldots h_{5}$. For example, the relative volume of the first zone in slice 1 was approximated by $h_{1} / H$. Although $H$ was constant for each slice, $h_{1} \ldots h_{5}$ should ideally represent an integrated mean boundary width not measurable for practical purposes. Within a narrow transitional zone the boundaries between the zones were

1 Insufficient quantity of cartilage for present purposes was obtainable by this technique from dog or human rib cages. 


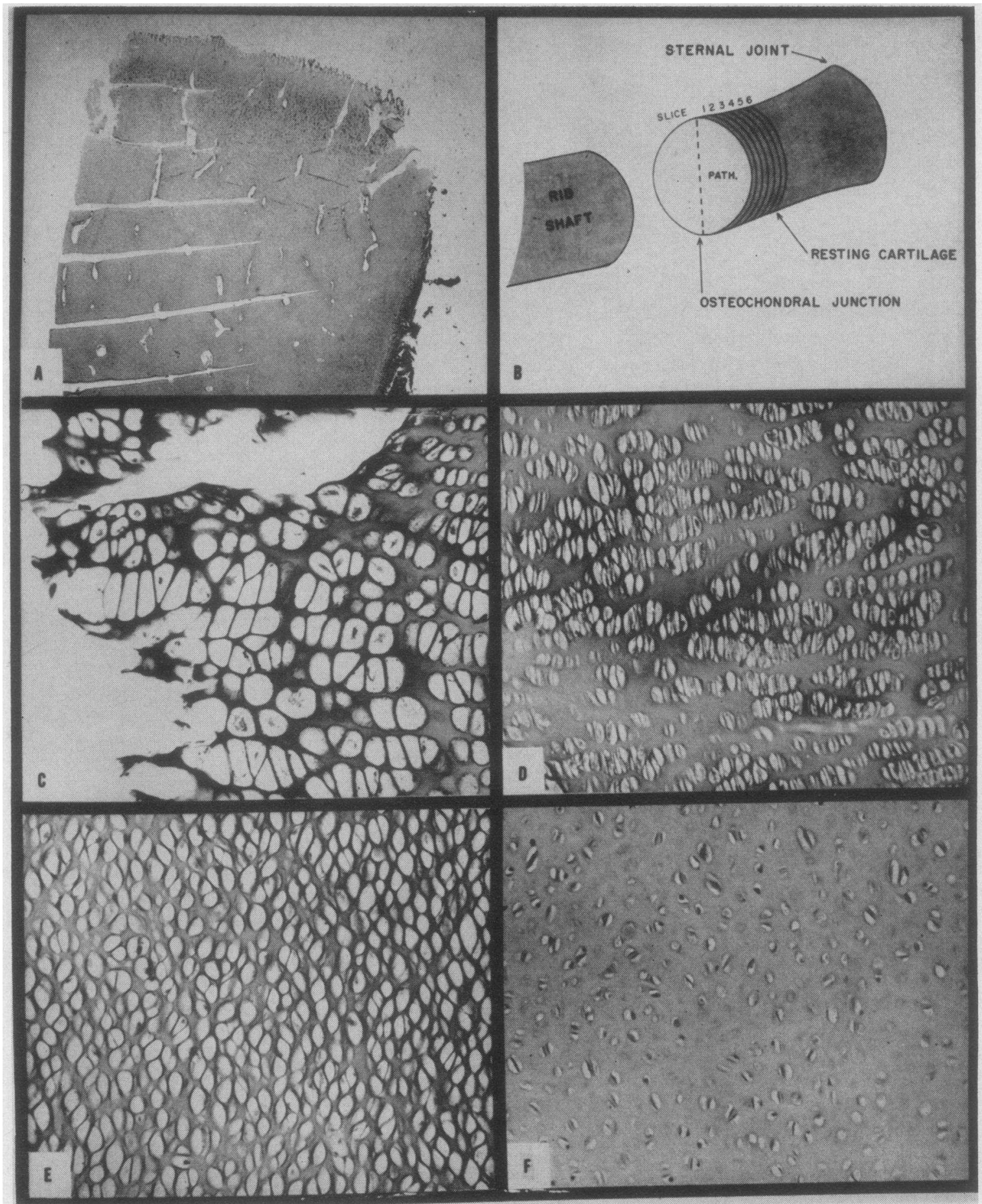

Fig. 1. Illustration of Cross-Sectional Slicing technique. A. 10× Photomicrograph of costochondral junction. Top slice corresponds to slice 1, and bottom slice to slice 6 of diagram B. Contents of slices 1 to 6 (B) are illustrated by diagrams $\mathrm{C}$ through $\mathrm{F}(440 \times$ photomicrographs). Slice 1 contains principally zones of provisional calcification and hypertrophic cells $(\mathrm{C})$, slices 2 and 3, proliferating cell (D) and aggregation cell (E) zones. Slices 5 and 6 contain aggregation cell (E) and resting cell (F) zones. 
remarkably parallel. Zonal and slice width were measured with a calibrated ocular micrometer at medial and peripheral ends of the slices. The latter measurements were used to calculate mean zonal widths in the 660 slices, on the assumption that the values represented a reasonable estimate of the "ideal" integrated mean boundary width (Table I).

Photomicrographs $(400 \times)$ obtained with a Leitz Aristophot assembly were made from fresh cartilage slices immediately after sectioning in cross-sectional and sagittal planes. Fresh and formalin-fixed tissues were photographed under identical conditions: $8 \times 10$ inch prints were assessed for changes due to formalin fixation. Eight separate $0.09 \mathrm{~mm}^{2}$ fields were randomly selected from each histological zone. ${ }^{2}$ The fraction of total field area (in per cent) occupied by cells presenting well defined cell margins was termed planar cell area. This measurement was made with a Bausch \& Lomb planimeter in both sagittal and cross-sectional planes, and the values averaged. The results were believed to reflect changes in ratio of cell volume to total tissue volume in a given zone. Cell counts were performed by the method of Rosenthal, Bowie and Wagoner, using the equations of Linderstrom-Lang (4). Results of the cell counts and measurements of zonal width within each slice were analyzed statistically (Tables I and II). Pooled cartilages from 11 rib cages were analyzed as follows. Samples were dried at $5^{\circ} \mathrm{C}$ under vacuum and ground to 60 mesh in a stainless steel mill. Fat extraction was found unnecessary. Samples from 8 of the rib cages were weighed, ashed at $700^{\circ} \mathrm{C}$ for 8 hours and the residues dissolved in $1 \mathrm{~N} \mathrm{HCl}$. These solutions were analyzed for calcium, sodium, potassium, phosphorus and magnesium. Sodium and potassium were determined with a Baird flame photometer by an internal standard method (5). Calcium was determined by titration with potassium permanganate after precipitation with am-

${ }^{2}$ The narrow zone of provisional calcification was excluded. monium oxalate (6). Phosphorus was determined by the method of Fiske and Subbarow (7). Magnesium was precipitated as magnesium ammonium phosphate after removal of calcium. This precipitate was analyzed by the Fiske and Subbarow method for phosphorus, and magnesium was calculated from these values (8). Chloride determinations were made by an amperometric titration method after extraction overnight at $5^{\circ} \mathrm{C}$ with $0.75 \mathrm{~N}$ nitric acid (personal communication with Dr. Ernest Cotlove). The benzidine precipitation method described by Dodgsen and Spencer was used for the analysis of sulfur (9) on samples extracted with nitric acid, as above, and hexosamines were determined by the method of Boas (10). For the determination of hexosamine-sulfur ratios dried samples were hydrolyzed with $6 \mathrm{~N} \mathrm{HCl}$. Total sulfur was used as an approximation of chondroitin sulfate content in cartilage slices. For justification, data of Meyer, Davidson, Linker and Hoffman (11) indicate that upon extraction and purification of chondroitin sulfate from young calf tracheal cartilage, 90 per cent or more of the total sulfur was found in this compound. In the present study, aqueous extracts of a variety of ground cartilage samples (before ashing) revealed slight or no inorganic sulfate by benzidine precipitation. Other evidence is provided by hexosamine-sulfur ratios predicted for chondroitin sulfate of approximately 1.0 in all 6 pooled samples of costal cartilage analyzed here $(\overline{\mathrm{X}}=0.96 ; \mathrm{SE}=0.037$; and 95 per cent $\mathrm{CL}=0.86$ to 1.05 ). The correction factor for recoveries of hexosamine ${ }^{3}$ was found to be approximately the same as that reported by Malawista and Schubert (12). Citrate was determined by a method of Natelson, Pincus and Lubovoy (13) for citric acid in

3 Percentage recovery of chloride, sulfate, and glucosamine added to cartilage samples carried through the entire procedure was: chloride, $\overline{\mathrm{X}}=97.3$; $\mathrm{SE} 1.6$; confidence limits $(C L)=93.3$ to $100 ; n=7$. Sulfate, $\bar{X}=$ 95.5; $\mathrm{SE} 1.5 ; \mathrm{CL}=92.4$ to $98.6 ; \mathrm{n}=26$. Glucosamine, $\overline{\mathrm{X}}=73.9 ; \mathrm{SE} 2.8 ; \mathrm{CL}=67.7$ to $80.0 ; \mathrm{n}=11$.

TABLE I

A comparison of the cell content and planar cell area in the histological zones of calf costal cartilage

\begin{tabular}{|c|c|c|c|c|}
\hline & $\begin{array}{l}\text { Hypertrophic } \\
\text { cells }\end{array}$ & $\begin{array}{l}\text { Proliferative } \\
\text { cells }\end{array}$ & $\begin{array}{c}\text { Aggregating } \\
\text { cells }\end{array}$ & $\begin{array}{c}\text { Resting } \\
\text { cells }\end{array}$ \\
\hline \multicolumn{5}{|l|}{ Cell content* } \\
\hline $\begin{array}{l}\overline{\mathrm{X}} \\
\mathrm{SE} \\
\mathrm{CL} \dagger \\
\mathrm{n}\end{array}$ & $\begin{array}{c}57.2 \\
0.98 \\
55.1-59.3 \\
14\end{array}$ & $\begin{array}{c}199.1 \\
4.33 \\
189.7-208.5 \\
14\end{array}$ & $\begin{array}{c}123.7 \\
1.76 \\
119.9-127.5 \\
14\end{array}$ & $\begin{array}{c}66.0 \\
1.14 \\
63.6-68.5 \\
14\end{array}$ \\
\hline \multicolumn{5}{|c|}{ Planar cell area $(\%)$} \\
\hline $\begin{array}{l}\bar{X} \\
\text { SE } \\
C L \\
n\end{array}$ & $\begin{array}{c}54.5 \\
2.45 \\
48.7-60.3 \\
8\end{array}$ & $\begin{array}{c}46.1 \\
3.96 \\
36.4-55.8 \\
7\end{array}$ & $\begin{array}{c}12.5 \\
0.56 \\
11.2-13.9 \\
8\end{array}$ & $\begin{array}{l}9.8 \\
1.48 \\
6.3-13.3 \\
8\end{array}$ \\
\hline
\end{tabular}

* Cell content $=$ number of cells per $\mathrm{mm}^{3}$ fixed tissue.

$+\mathrm{CL}=95 \%$ confidence limits. 
serum. For this determination, samples of dried ground cartilage weighing between 50 and $150 \mathrm{mg}$ were hydrolyzed with $2 \mathrm{ml}$ of $2 \mathrm{~N} \mathrm{HCl}$ in sealed glass tubes for 8 hours in an oven at $110^{\circ} \mathrm{C}$. Citrate determinations were made on the hydrolysates. The carbon dioxide content was estimated by the method of Eichelberger and Roma (1). Total nitrogen was measured on wet-digested samples by the Conway microdiffusion technique (14) and hydroxyproline content was determined by the method of Neuman and Logan (15). From the latter values collagen nitrogen was derived by the following equations : hydroxyproline $\times 7.46 / 5.56=$ collagen $\mathrm{N}(16)$. Three samples of cartilage from the inactive zone were fractionated by extraction with 20 per cent trichloroacetic acid (17). Phosphate content on the fractions was determined as previously described. Histochemical identification of inorganic phosphates by the Von Kossa staining procedure and of calcium by the alizarin red $\mathrm{S}$ method of Dahl was used for detecting bone salt deposits (18). Statistical analyses included the use of confidence limits : 95 per cent confidence interval $=\overline{\mathrm{X}} \pm$ [ $t_{0.05} \times$ standard error] (19).

\section{RESULTS}

Histological measurements. Results of the zonal analysis, together with the 95 per cent confidence limits, are shown in Table II. Pooled first slices contained all of the zone of provisional calcification and most of the hypertrophic zone. In addition, about one-fifth the width of this slice was composed of the proliferating cell zone. Pooled second slices contained vestiges of hypertrophic and resting cell zones but primarily proliferating and aggregation cells in equal proportions. Pooled third slices differed from the pooled second slices by the predominance of the aggregation cell zone and the virtual absence of the hypertrophic cell zone. Slices 4, 5 and 6 contained the aggregation and resting cell zones with only a trace of the former remaining in slice 6 . Ninety-five per cent confidence limits revealed the greatest variation, 1 to 41 per cent, in the magnitude of the proliferating cell fraction of slice 3 . Otherwise there was only moderate variation in zonal composition, unlikely to disturb an approximate correlation with chemical determinations.

The results of cell counts (Table I) were similar to those obtained by Rosenthal and colleagues in a study of calf epiphyseal cartilage (4).

TABLE II

Histological zonal analysis on cross-sectional slices of costal cartilage

\begin{tabular}{|c|c|c|c|c|c|c|c|}
\hline & & \multicolumn{6}{|c|}{ Slice number } \\
\hline & & 1 & 2 & 3 & 4 & 5 & 6 \\
\hline & & $\%$ & $\%$ & $\%$ & $\%$ & $\%$ & $\%$ \\
\hline \multicolumn{8}{|c|}{ Cellular type } \\
\hline \multicolumn{8}{|c|}{ Provisional calcification } \\
\hline \multirow[t]{3}{*}{ A } & $\overline{\mathrm{X}}$ & 7 & & & & & \\
\hline & $\mathrm{SE}$ & 0.7 & 0 & 0 & 0 & 0 & 0 \\
\hline & $\overline{C L}$ & & & & & & \\
\hline \multicolumn{8}{|c|}{ Hypertrophy } \\
\hline B & $\overline{\mathrm{X}}$ & & 7 & 0.5 & 0 & 0 & 0 \\
\hline & SE & 3.4 & 2.1 & 0.5 & & & \\
\hline & $\mathrm{CL}$ & $59-74$ & & & & & \\
\hline \multicolumn{8}{|c|}{ Proliferating } \\
\hline $\mathrm{C}$ & $\overline{\mathrm{X}}$ & & & 21 & 0.1 & 1.1 & 0 \\
\hline & $\begin{array}{l}\mathrm{SE} \\
\mathrm{CL}\end{array}$ & $\begin{array}{c}2.8 \\
17-30\end{array}$ & $\begin{array}{c}6.2 \\
34-62\end{array}$ & $\begin{array}{l}9 \\
1-41\end{array}$ & $\begin{array}{c}0.1 \\
\text { to } 0.4\end{array}$ & $\begin{array}{c}1 \\
\text { to } 3\end{array}$ & \\
\hline \multicolumn{8}{|c|}{ Aggregation } \\
\hline $\mathrm{D}$ & $\overline{\mathrm{x}}$ & 0.5 & & 73 & 67 & 30 & 2 \\
\hline & $\mathrm{SE}$ & 0.2 & 6.8 & 8.2 & 6.6 & 4.4 & 0.7 \\
\hline & $\mathrm{CL}$ & to 1 & $30-60$ & 54-91 & $52-81$ & $20-40$ & $0.6-3.9$ \\
\hline \multicolumn{8}{|c|}{ Resting cell } \\
\hline $\mathrm{E}$ & $\overline{\mathrm{X}}$ & 0 & 2 & & & & \\
\hline & SE & & 1.1 & 2.6 & 6.7 & $\begin{array}{r}00 \\
5\end{array}$ & 1.8 \\
\hline & $\mathrm{CL}$ & & to 4 & to 12 & $16-46$ & $57-79$ & $92-99$ \\
\hline
\end{tabular}




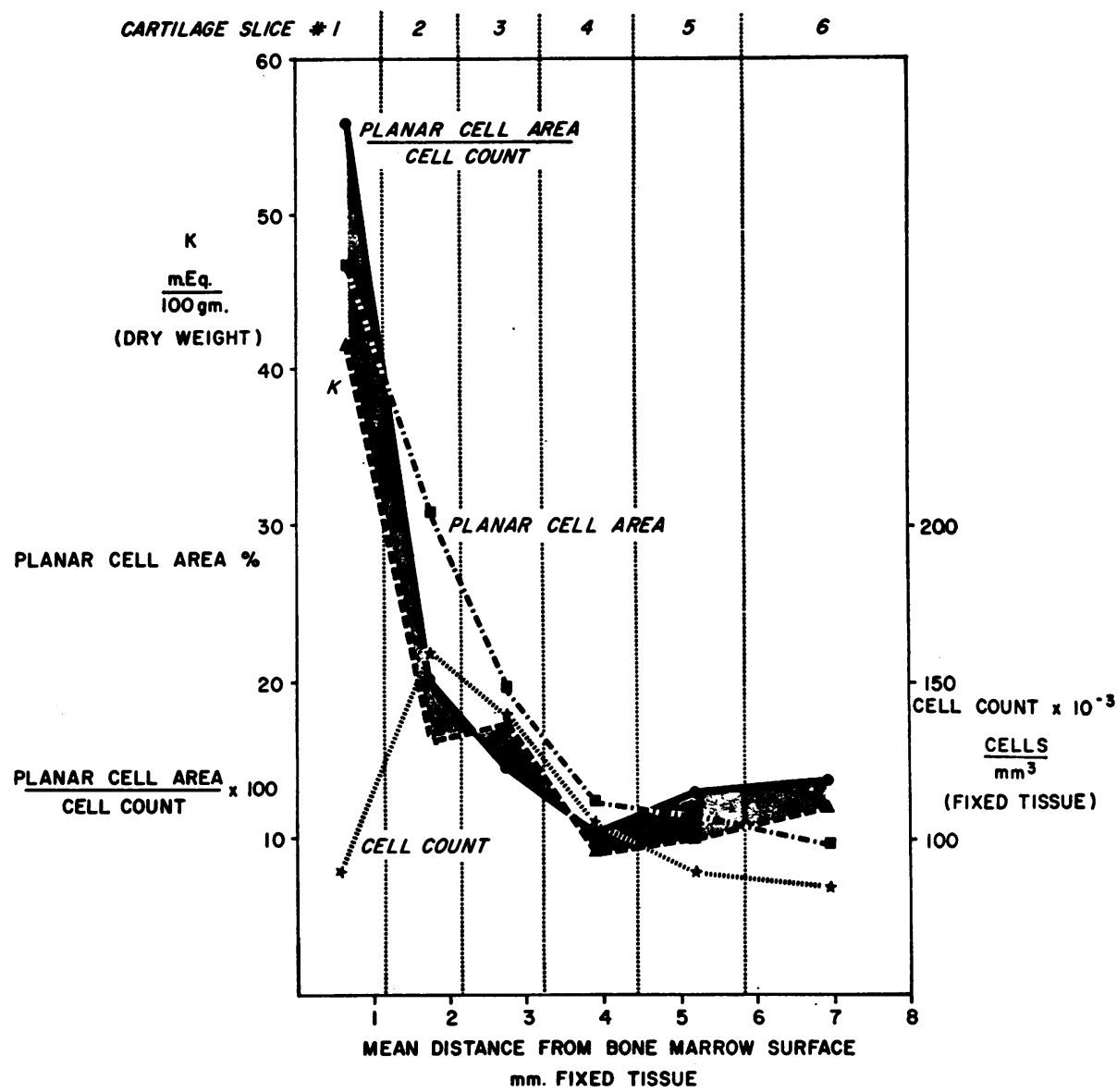

Fig. 2. Cell count, planar cell area and potassium concentration in Cross-secTIONAL SLICES OF COSTAL CARTILAGE. A large rise of potassium concentration and planar cell area is observed in the pooled first slices, with a reciprocal decline in cell count. The ratio of planar cell area to cell count provides an index of cellular hyperplasia.

In order to appraise cell concentration within a given slice, random counts on constituent zones were weighted according to the relative width of the zone within each slice and an approximate cell count was derived (Figure 2). In the first slice the prevalence of hypertrophic cells accounted for the low figure of $85 \times 10^{3}$ cells per $\mathrm{mm}^{3}$. Pooled second slices contained predominantly proliferating cells with a count of $160 \times$ $10^{3}$ cells per $\mathrm{mm}^{3}$. From slices 3 to 6 the cell count gradually fell to $60 \times 10^{3}$ cells per $\mathrm{mm}^{3}$.

The relationship of planar cell area to cell count (Figure 2) was close in slices 2 through 6 , but marked reciprocal changes were noted in slice 1 .

Total nitrogen and collagen nitrogen. In confirmation of histological studies on the fiber content of cartilage samples, collagen content (hy- droxyproline $\times 7.46$ ) increased $^{4}$ progressively from slices 1 through 6 , correlating negatively with planar cell area (Table III). Total nitrogen measured in pooled slices 4 through 6 was slightly lower than expected from previous studies $(\overline{\mathrm{X}}=$ 9.66; $\mathrm{SE} 1.12$; 95 per cent $\mathrm{CL}=4.83$ to 14.48 ; $\mathrm{n}=12$ ) (1). In addition to cellular components, the noncollagenous nitrogenous material is probably in part composed of mucoprotein, demonstrated in cartilage by Shatton and Schubert (20).

Electrolytes. The potassium levels in the pooled first slices decreased strikingly from 41 to $16 \mathrm{mEq}$ per $100 \mathrm{~g}$ in pooled second slices, with a subse-

4 These terms are used to indicate trend of concentration with no implication of flux. 
TABLE III

Results of chemical analyses of pooled calf cartilage slices

\begin{tabular}{|c|c|c|c|c|}
\hline \multicolumn{2}{|c|}{$\begin{array}{l}\text { Pools of } \\
\text { slices }\end{array}$} & $\mathrm{H}_{2} \mathrm{O}$ & Hydroxyproline & Collagen $\mathrm{N}^{*}$ \\
\hline & no. & $\begin{array}{c}\mathrm{ml} / 100 \mathrm{~g} \\
\text { whole wet tissue }\end{array}$ & $\mathrm{g} / 100 \mathrm{~g} \dagger$ & $\mathrm{g} / 100 \mathrm{~g} \dagger$ \\
\hline 1 & $\begin{array}{l}\bar{X} \\
\text { SE } \\
\text { CL }\end{array}$ & $\begin{array}{l}77.6 \\
1.5 \\
73.4-81.9\end{array}$ & $\begin{array}{l}3.10 \\
0.24 \\
2.44-3.78\end{array}$ & 4.16 \\
\hline 2 & $\begin{array}{l}\overline{\mathrm{X}} \\
\mathrm{SE} \\
\mathrm{CL}\end{array}$ & $\begin{array}{l}81.6 \\
2.2 \\
75.6-87.6\end{array}$ & $\begin{array}{l}3.50 \\
0.16 \\
3.08-3.92\end{array}$ & 4.70 \\
\hline 3 & $\begin{array}{l}\bar{X} \\
\text { SE } \\
\text { CL }\end{array}$ & $\begin{array}{l}79.0 \\
1.7 \\
74.2-83.8\end{array}$ & $\begin{array}{l}4.28 \\
0.40 \\
3.18-5.38\end{array}$ & 5.75 \\
\hline 4 & $\begin{array}{l}\bar{X} \\
\text { SE } \\
\text { CL }\end{array}$ & $\begin{array}{l}80.6 \\
1.1 \\
77.7-83.6\end{array}$ & $\begin{array}{l}4.88 \\
0.32 \\
2.98-5.80\end{array}$ & 6.54 \\
\hline 5 & $\begin{array}{l}\bar{X} \\
\text { SE } \\
\text { CL }\end{array}$ & $\begin{array}{l}78.1 \\
1.5 \\
73.9-82.3\end{array}$ & $\begin{array}{l}5.50 \\
0.58 \\
3.02-7.98\end{array}$ & 7.38 \\
\hline 6 & $\begin{array}{l}\bar{X} \\
\text { SE } \\
\text { CL }\end{array}$ & $\begin{array}{l}76.9 \\
2.2 \\
70.8-83.0\end{array}$ & $\begin{array}{l}6.14 \\
0.14 \\
5.58-6.70\end{array}$ & 8.24 \\
\hline & $\mathrm{n}$ & 5 & $\begin{array}{c}\text { Slices 1-4: } \\
n=5 \\
\text { Slices } 5,6: \\
n=3\end{array}$ & \\
\hline
\end{tabular}

$\frac{7.46}{5.56} \times$ Hydroxyproline $=$ collagen $\mathrm{N}$.

$\dagger$ Dry weight. quent slight or insignificant decrease to $12 \mathrm{mEq}$ in slices 3 to 6 (Table IV). The correlation of potassium content with derived cell count and planar cell area (Figure 2) was close in slices 3 through 6; however, in slice 1 potassium content correlated positively with planar cell area and negatively with the cell count.

Total sodium remained essentially unchanged in slices 1 to 3 at 100 to $110 \mathrm{mEq}$ per $100 \mathrm{~g}$ but subsequently declined to $64.9 \mathrm{mEq}$ per $100 \mathrm{~g}$ in slice 6. Chloride remained remarkably constant at the level of 23.3 to $29.5 \mathrm{mEq}$ per $100 \mathrm{~g}$ throughout the 6 slices (Table IV). Total sulfur, 58 mmoles per $100 \mathrm{~g}$ in both slices 1 and 2 decreased gradually to 29.9 mmoles in slice 6 (Table IV).

Calcium content decreased from 98.7 in slice 1 to $6.8 \mathrm{mmoles}$ per $100 \mathrm{~g}$ in slice 6 (Table IV). Von Kossa and alizarin red S stains of slices histologically studied in 20 cartilages randomly selected from seven rib cages indicated that slice 1 was contaminated with small but variable amounts of trabecular bone which could not be completely scraped from the cartilage surface. Scrapings from the surface of slice 1 gave a calcium: phosphorus ratio of 1.48 whereas this ratio was 1.70 in seven pools of slice 1 . These values were within the range expected for hydroxyapatite, 1.3

TABLE IV

Electrolytic distribution in calf costal cartilage*

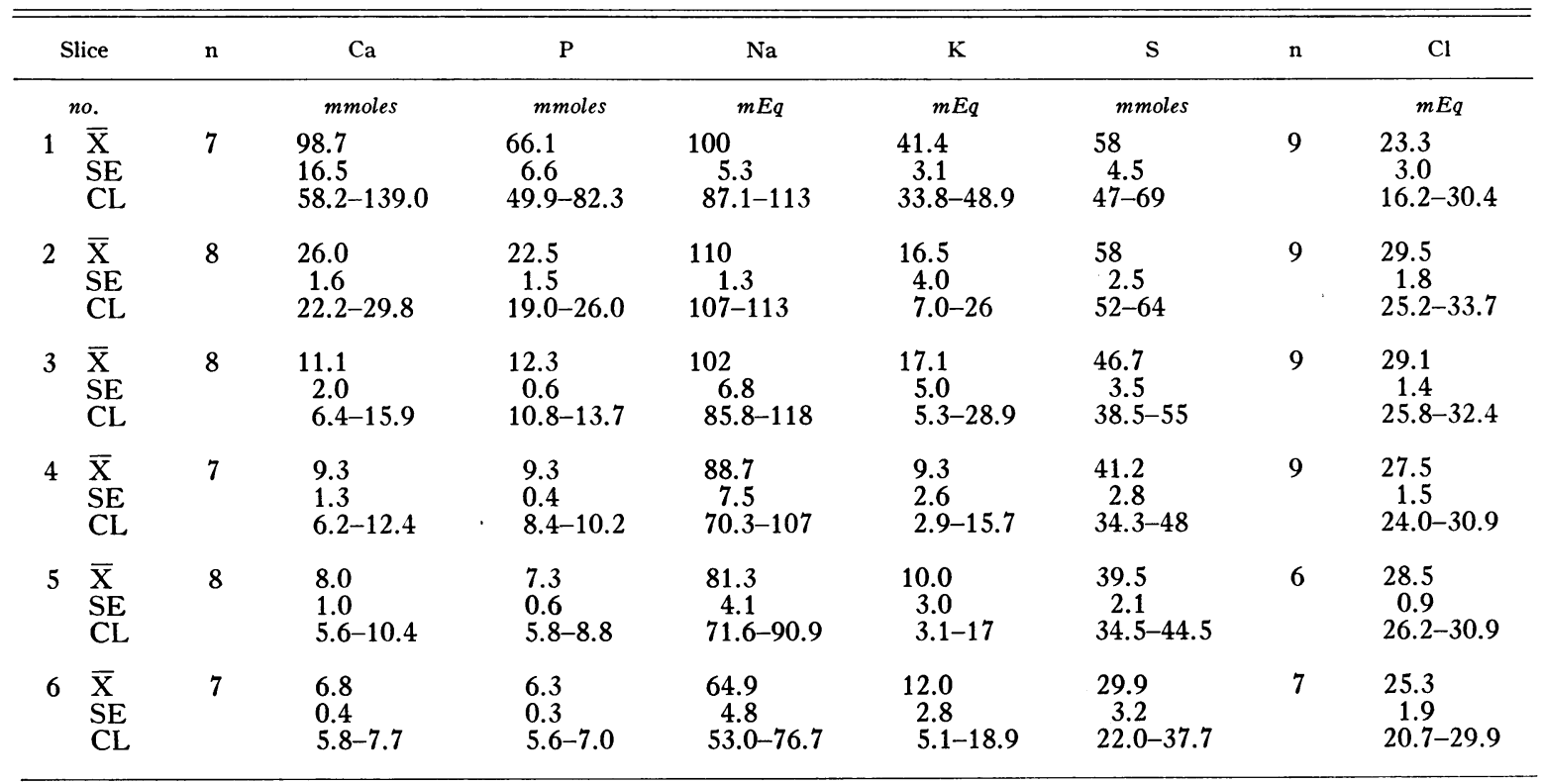

* Units per $100 \mathrm{~g}$ dry solids. 
TABLE $V$

Minor electrolytic constituents of calf costal cartilage*

\begin{tabular}{|c|c|c|c|c|c|c|c|}
\hline \multicolumn{2}{|r|}{ Slice } & $\mathbf{n}$ & $\mathbf{M g}$ & $\mathrm{n}$ & Citrate & $\mathbf{n}$ & $\mathrm{CO}_{2}$ \\
\hline & no. & & mmoles & & $m g$ & & mmoles \\
\hline 1 & $\begin{array}{l}\overline{\mathbf{X}} \\
\mathrm{SE} \\
\mathrm{UCL}+\end{array}$ & 3 & $\begin{array}{r}9.63 \\
0.23 \\
10.64\end{array}$ & 3 & $\begin{array}{r}212 \\
53 \\
440\end{array}$ & 3 & $\begin{array}{r}9.53 \\
2.58 \\
20.62\end{array}$ \\
\hline 2 & $\begin{array}{l}\bar{X} \\
\text { SE } \\
\text { UCL }\end{array}$ & 4 & $\begin{array}{r}5.25 \\
1.51 \\
10.07\end{array}$ & 3 & $\begin{array}{r}87 \\
15 \\
153\end{array}$ & 4 & $\begin{array}{l}4.52 \\
1.18 \\
8.27\end{array}$ \\
\hline 3 & $\begin{array}{l}\bar{X} \\
\text { SE } \\
U C L\end{array}$ & 3 & $\begin{array}{r}5.93 \\
2.48 \\
16.62\end{array}$ & 3 & $\begin{array}{r}50 \\
8 \\
85\end{array}$ & 4 & $\begin{array}{l}4.50 \\
0.44 \\
5.89\end{array}$ \\
\hline 4 & $\begin{array}{l}\bar{X} \\
\text { SE } \\
\text { UCL }\end{array}$ & 3 & $\begin{array}{l}4.77 \\
1.04 \\
9.24\end{array}$ & 3 & $\begin{array}{r}54 \\
13 \\
109\end{array}$ & 4 & $\begin{array}{l}4.92 \\
1.08 \\
8.36\end{array}$ \\
\hline 5 & $\begin{array}{l}\bar{X} \\
\text { SE } \\
\text { UCL }\end{array}$ & 3 & $\begin{array}{l}4.57 \\
0.94 \\
8.59\end{array}$ & 3 & $\begin{array}{r}49 \\
2 \\
57\end{array}$ & 3 & $\begin{array}{l}4.37 \\
0.77 \\
4.67\end{array}$ \\
\hline 6 & $\begin{array}{l}\bar{X} \\
\text { SE } \\
\text { UCL }\end{array}$ & 3 & $\begin{array}{r}4.63 \\
1.50 \\
11.10\end{array}$ & 3 & $\begin{array}{r}46 \\
3 \\
57\end{array}$ & & \\
\hline
\end{tabular}

* Units per $100 \mathrm{~g}$ dry solids.

$\dagger \mathrm{UCL}=95 \%$ confidence limit (upper value).

to 2.0 (21). In slice 2 histological examination of the opposite halves of all slices analyzed chemically showed no evidence of contamination with pooled slices 1 , and in all sections of slice 2 only slight and scattered Von Kossa-positive staining material was seen. Thus the higher calcium levels in slice 2 seemed due to storage of calcium in this layer, rather than to contamination with bone salt. In slices 3 to 6 the calcium concentration fell markedly but remained 10 to 20 times the concentration of this ion in other tissue such as liver or muscle (22), and 'Von Kossa-staining material was absent.

The total content of phosphorus decreased from 66.1 in slice 1 , to 22.5 mmoles per $100 \mathrm{~g}$ in slice 2 , and decreased further to 6.3 mmoles per $100 \mathrm{~g}$ in slice 6 (Table IV). The trichloroacetic acidextractable phosphorus, considered by Whitehead and Weidman to include all of the inorganic phosphates, was one-third to one-half of the total phosphorus in the inactive zone (17). Because of the laborious nature of histological correlation, only limited numbers of samples were available for minor electrolytes (Table V), but the needed gross estimate of their content was obtained.
Magnesium decreased from 9.6 in slice 1 to 4.6 mmoles per $\mathrm{g}$ in slice 6 . Carbon dioxide declined from 9.5 in slice 1 to 4.4 mmoles per $100 \mathrm{~g}$ in slice 5 , whereas citrate, $212 \mathrm{mg}$ in slice 1 , fell gradually to $46 \mathrm{mg}$ in slice 6 (Table V).

\section{DISCUSSION}

1. Sodium and chloride. Based on current concepts of sodium metabolism in bone and other tissues a partition of sodium in cartilage would include, at the least, 1) a dissociated form in extracellular lymph; 2) a moiety associated with chondroitin sulfate and possibly other acid mucopolysaccharides; 3) a fraction bound to surfaces of hydroxyapatite crystals; and 4) a small intracellular content. A maximal limit of sodium associated with chondroitin sulfate based on the assumption that each millimole of sulfur represents 1 milliperiod of chondroitin sulfate is shown in Figure 3 for the cartilage slices. A slope of sul-

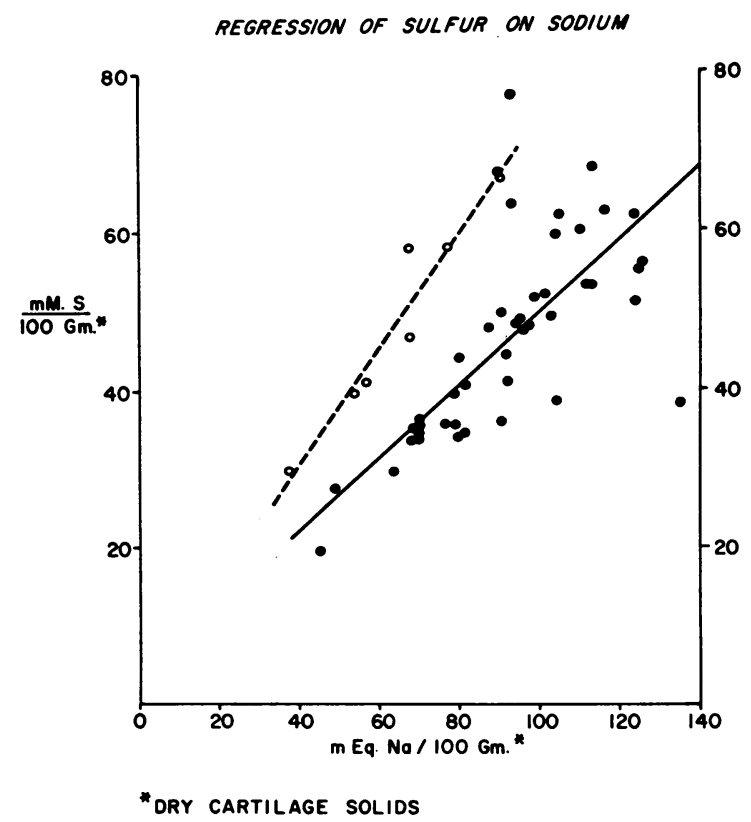

Fig. 3. The Regression OF SUlfur ON SODIUM IN CRoss-SECtional slices of costal Cartilage. The theoretical maximal association of sodium with chondroitin sulfate is used in the plot $(24,25)$ shown by the continuous line; slope $=0.46$. Nonchloride sodium (total sodium - chloride equivalent of sodium) approximates more closely that fraction available for association with chondroitin sulfate (dashed line slope $=0.72$ ). The estimate neglects the unknown net effect of minor ions in cartilage lymph. 
fur-on-sodium regression of 0.5 would be predicted for maximal association of $2.0 \mathrm{mEq}$ per milliperiod (see Section 5 below). The mean slope was close to this predicted value- -0.46 (Figure 3). However, the actual restriction of this maximal figure to sodium seems unlikely. First, in the absence of chloride-binding to protein or an unusual intracellular content most of the chloride would be expected to be freely dissociated with an equivalent content of sodium predominantly in the matrix lymph. Correction for sodium theoretically associated with chloride provides a slope of 0.72 (Figure 3 ). Association of calcium and other extracellular cations in small amounts with chondroitin sulfate is believed to account for this difference of slope. Chloride concentration in all slices was remarkably constant despite large differences in cell volume and fiber content (Table IV).

2. Potassium. The relatively high level of potassium in the pooled first slices, containing 60 to 75 per cent of the hypertrophic cell zone, is of interest because a much smaller change of potassium content occurs across slices 2 through 4 containing most of the proliferating cell zone. Also, no significant contribution to the level of potassium in slice 1 was made by bone salt, which contains negligible amounts of this ion (23). Thus, the high content of potassium was almost certainly associated with the zone of hypertrophic cells. The reason for this high level of potassium in the first slice is unknown and might reflect either the high metabolic activity (2) of this layer or simply a higher fraction of cell volume.

3. Calcium and phosphorus. In regard to this partition it is anticipated that calcium would be stored in epiphyses or in the growing costochondral junction in at least three phases: 1) hydroxyapatite, 2) extracellular lymph bathing the cartilage matrix, and 3) forms associated with chondroitin sulfate or other acid mucopolysaccharide fractions within the matrix (1). It was expected that phosphorus would be stored predominantly as 1) hydroxyapatite, 2) $\mathrm{HPO}_{4}-$ $\mathrm{H}_{2} \mathrm{PO}_{4}$ buffer in extracellular lymph, 3) intracellular organic and inorganic phosphate, and 4) possibly matrix polyphosphates (21). The present data shed light on certain features of the relationship of calcium to phosphorus across the cartilage plate.
From histological evidence (absence of deposits stained by Von Kossa's method), calcium, at levels of 7 to 26 mmoles per $100 \mathrm{~g}$, is believed to be all or in large part available for association with other anionic components of the matrix such as chondroitin sulfate. If this calcium, partially bound in the matrix, were released at the site of calcification it would provide an excellent source of ionized calcium in the formation of hydroxyapatite.

4. Magnesium, bicarbonate and citrate. These ions contribute little to total ionic activity unless localized in a small region, and slice 1 contained the largest amount (Table V). The partition of these ions between cells and matrix is uncertain and a fraction of $\mathrm{CO}_{2}$ in slice 1 may be carbonate. Because both magnesium and citrate have been shown to have inhibitory action on bone salt deposition (21) they were measured here on the presumption that concentrations of one or the other might be higher in the regions lacking bone salt. The large difference among slices in numbers of cells could obscure extracellular changes of these ions.

5. Composite electrolyte profile. Distinguishing features of an electrolyte profile in young costal cartilage probably result in large measure from the cation-retaining properties of chondroitin sulfate. Boyd and Neuman considered the cartilage matrix to behave as an ion-exchange resin and found an equal capacity of ethylenediamine tetraacetate-extracted cartilage to retain sodium, calcium or barium, at $2 \mathrm{mEq}$ per mmole of sulfur or milliperiod of chondroitin sulfate (24). Since each repeating unit or milliperiod of chondroitin sulfate is composed of glucuronic acid linked to sulfated $\mathrm{N}$-acetyl-galactosamine, the findings of Boyd and Neuman suggested complete availability of the carboxyl and sulfate groups in this compound for association with cations. Similarly, in equilibrium dialysis studies on purified chondroitin sulfate and chondromucoprotein, Farber and Schubert showed almost total availability of these radicals for association with cations at neutral $\mathrm{pH}$ (25). The purpose of the present electrolyte profiles was to estimate in relation to histological regions the total availability of anionic radicals of chondroitin sulfate as well as the composition of associated cations. In previous studies, both increased association of calcium with 
chondroitin sulfate (1) and, conversely, loss of sulfate from chondroitin preliminary to bone salt deposition, have been postulated (26). If such changes commenced in the hypertrophic and proliferative cell zones preliminary to chondral calcification, they should be reflected in the electrolyte profile specifically of these regions. A profile of current electrolyte data is presented in Figure 4. In this model it is assumed that 1) total sulfur provides a reasonable approximation of chondroitin sulfate content ${ }^{3,5} ; 2$ ) the predominant cation associated with chondroitin sulfate is sodium; and 3) most of the potassium, phosphate and magnesium are intracellular. In all slices there is for the extracellular phase a gap of anions similar to that demonstrable in plasma due to cationic association with plasma proteins. This gap for electroequivalency in cartilage, however, should, if chondroitin sulfate is the only major extracellular macroanion, provide a crude estimate of its available negative charges. The macroanion column $(\mathrm{Ma})$ is arbitrarily calculated on the basis of $2 \mathrm{mEq}$ per mmole sulfur measured or

5 This is true in young animals in which keratosulfate is not yet quantitatively an important constituent (27). total availability of carboxyl and sulfate groups; in support of data of the authors quoted above $(24,25)$, the sum of theoretically extracellular cations and anion components is close in slices 2 to 6 involving a 100 per cent change of sulfur content. Electrolyte profile of slice 1 (not shown) was almost identical with slice 2 except for the presence of bone salt. These results provide evidence favoring availability of the major fraction of the anionic radicals on chondroitin sulfate across the width of the epiphyseal plate. The profiles show an increase of calcium across the proliferating cell zone but in none of the pooled slices of cartilage was there evidence for a decrease in sulfate content adjacent to new bone salt deposition. Ultra-thin, pooled slices $(0.1 \mathrm{~mm}$ thick) including only the hypertrophic zone and that of provisional calcification (unpublished observations) have provided electrolyte profiles similar to that of slices 1 and 2 .

6. Uses for the method. The results of this study indicate that the costochondral junction is a tissue of quite reproducible composition in regard to histological structure, nitrogen, hydroxyproline and water content. By pooling like slices

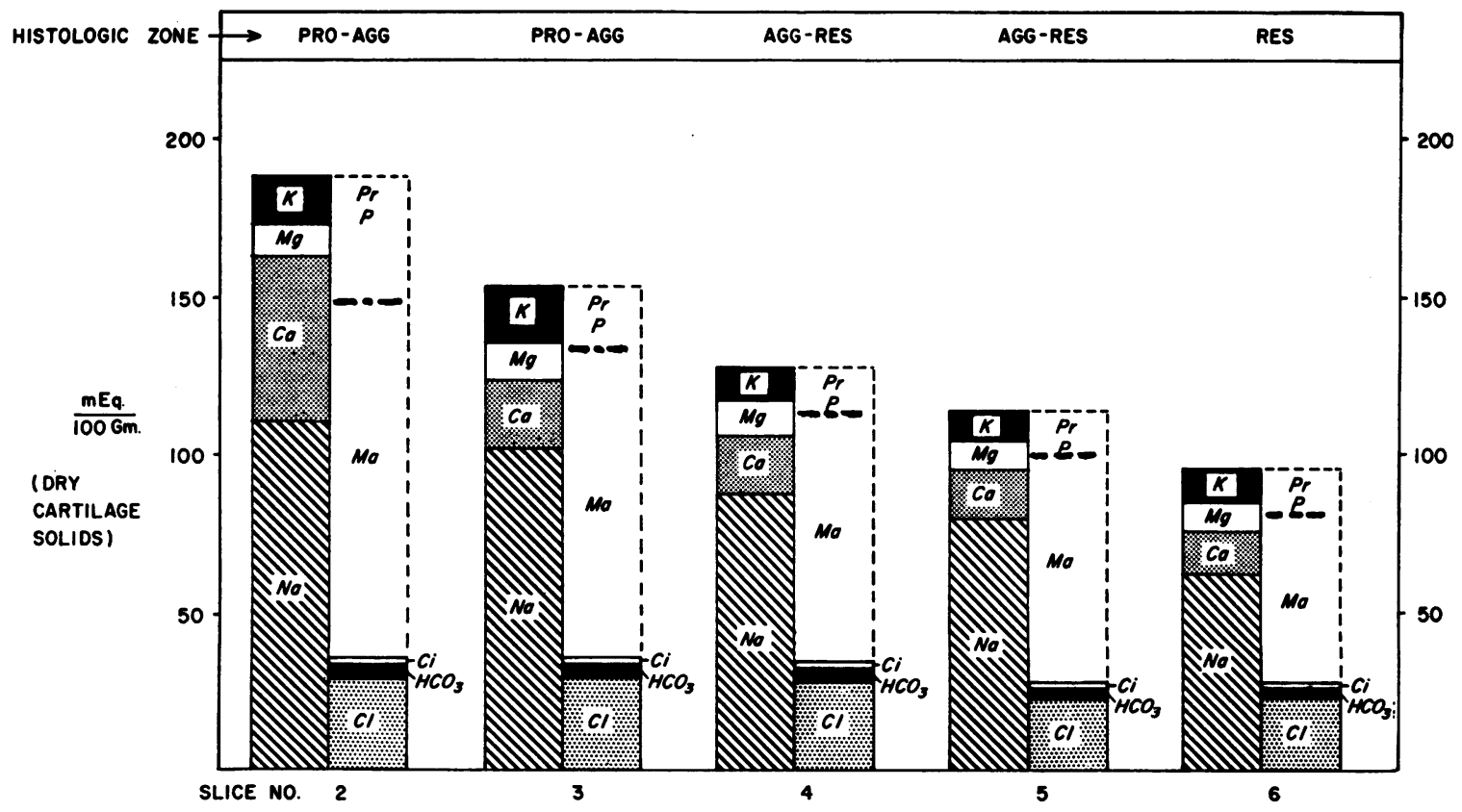

Fig. 4. Partition of electrolytes in Relation to histological zones of costal cartilage. Mean values for cation and anion concentrations in costal cartilage are summed for pooled slices 2 through 6 . Abbreviations include: $\mathrm{PRO}-\mathrm{AGG}=$ zones of proliferating cells and aggregating cells; AGG-RES = zones of aggregating and resting cells; $\mathrm{RES}=$ zone of resting cells; $\mathrm{Ma}, \mathrm{Pr}, \mathrm{P}=$ matrix acid mucopolysaccharides, proteinate, phosphate. 
in the manner described, sufficient material is obtained for physicochemical, electrolytic and enzymatic studies. In this manner chemical activity can be correlated with histological zones. The technique should be adaptable to investigation of mechanisms concerning provisional calcification of cartilage and electrolytic storage. In regard to the latter, available techniques for partitioning electrolyte concentrations in fluid compartments of other tissues based on Donnan equilibria (1, 22) require re-examination and probable modification depending largely upon the physicochemical state of matrix macroanions. Studies of thermoelastic properties of various tissues (e.g., muscle) have been deterred by inability to separate the influence of cellular, fibrillar, electrolytic and other constituents on the given parameter measured on whole tissue $(28,29)$. Thus, this method for the study of the thermoelastic properties of aging cartilage (30), in which cartilage of widely varying but reproducible content of the above constituents may be sampled, is proving to be useful.

\section{SUMMARY AND CONCLUSION}

1. A method has been described by which quantitative electrolytic determinations on pooled calfrib costochondral junctions may be correlated with histological structure of the epiphyseal plate.

2. In comparison with resting cell tissue the hypertrophic and proliferating cell zones showed a four- to sixfold greater relative cell volume, threefold higher potassium, twofold greater sulfur content, twofold larger amount of sodium in excess of the theoretical equivalent associated with chloride, 50 per cent smaller content of collagen nitrogen, variably elevated levels of calcium and phosphorus due to hydroxyapatite deposition, and two- to fivefold higher levels of magnesium, carbonate and citrate. Chloride content changed only slightly across these zones.

3. The method should prove useful in enzymatic, electrolytic and thermoelastic studies of growing cartilage.

\section{ACKNOWLEDGMENT}

The authors are indebted to Dr. Ernest Cotlove, of the National Heart Institute, Bethesda, Md., for helpful criticisms.

\section{REFERENCES}

1. Eichelberger, L., and Roma, M. Effects of age on the histochemical characterization of costal cartilage. Amer. J. Physiol. 1954, 178, 296.

2. Leblond, C. P., and Greulich, R. C. Autoradiographic studies of bone formation and growth in The Biochemistry and Physiology of Bone, G. H. Bourne, Ed. New York, Academic Press, 1956, p. 334.

3. Follis, R. H., Jr. Studies on the chemical differentiation of developing cartilage and bone. I. General method. Alkaline phosphatase activity. Johns Hopk. Hosp. Bull. 1949, 85, 360.

4. Rosenthal, O., Bowie, M. A., and Wagoner, G. Studies in the metabolism of articular cartilage; respiration and glycolysis of cartilage in relation to its age. J. cell. comp. Physiol. 1941, 17, 221.

5. Baird Associates Flame Photometer Manual. Cambridge, Mass., Baird Assoc., Inc., 1956, p. 32.

6. Willard, H. H., and Furman, N. H. Elementary Quantitative Analysis. New York, D. Van Nostrand, 1940, p. 235.

7. Consolazio, C. F., Johnson, R. E., and Marek, E. Metabolic Methods. St. Louis, C. V. Mosby, 1951, p. 109.

8. Briggs, A. P. A colorimetric method for the determination of small amounts of magnesium. J. biol. Chem. 1922, 52, 349.

9. Dodgson, K. S., and Spencer, B. Assay of Sulfatases in Methods of Biochemical Analysis, D. Glick, Ed. New York, Interscience Publishers, Inc., 1957, vol. 4, p. 220.

10. Boas, N. F. Method for the determination of hexosamines in tissues. J. biol. Chem. 1953, 204, 553.

11. Meyer, K., Davidson, E., Linker, A., and Hoffman, P. The acid mucopolysaccharides of connective tissue. Biochim. biophys. Acta 1956, 21, 506.

12. Malawista, I., and Schubert, M. Chondromucoprotein: New extraction method and alkaline degradation. J. biol. Chem. 1958, 230, 535.

13. Natelson, S., Pincus, J. B., and Lugovoy, J. K. Microestimation of citric acid; a new colorimetric reaction for pentabromoacetone. J. biol. Chem. 1948, 175, 745 .

14. Conway, E. J. Microdiffusion Analysis and Volumetric Error, 3rd ed. London, Croshy Lockwood, 1950 , p. 124.

15. Neuman, R. E., and Logan, M. A. The determination of hydroxyproline. J. biol. Chem. 1950, 184, 299.

16. Gustavson, K. H. The Chemistry and Reactivity of Collagen. New York, Academic Press, 1956, p. 39.

17. Whitehead, R. G., and Weidman, S. M. Fractionation of phosphorus compounds in ossifying cartilage. Nature (Lond.) 1957, 180, 1196.

18. Lillie, R. D. Histopathologic Technique and Practical Histochemistry. Philadelphia, Blakiston, 1954, p. 263. 
19. Mainland, D. Statistics in medical research, Section 3. Meth. med. Res. 1954, 6, 121.

20. Shatton, J., and Schubert, M. Isolation of a mucoprotein from cartilage. J. biol. Chem. 1954, 211, 565.

21. Neuman, W. F., and Neuman, M. W. The Chemical Dynamics of Bone Mineral. Chicago, Univ. of Chicago Press, 1958.

22. Manery, J. F. Water and electrolyte metabolism. Physiol. Rev. 1954, 34, 334.

23. Eastoe, J. E. The organic matrix of bone in The Biochemistry and Physiology of Bone, G. H. Bourne, Ed. New York, Academic Press, 1956, p. 81.

24. Boyd, E. S., and Neuman, W. F. The ion-binding properties of cartilage. J. biol. Chem. 1951, 193, 243.
25. Farber, S. J., and Schubert, M. The binding of cations by chondroitin sulfate. $\mathrm{J}$. clin. Invest. 1957, 36, 1715.

26. Logan, M. A. Composition of cartilage, bone, dentin and enamel. J. biol. Chem. 1935, 110, 375.

27. Meyer, K., Hoffman, P., and Linker, A. Mucopolysaccharides of costal cartilage. Science 1958, 128, 896.

28. Carlson, F. D. Kinematic Studies on Mechanical Properties of Muscle. Tissue Elasticity, J. W. Remington, Ed. Washington, D. C., Amer. Physiol. Soc. 1957 , p. 55.

29. Elden, H., and Howell, D. S. Effects of electrolytes on contraction-elongation phenomena in rat tail tendons. Gordon Conference on Bones and Teeth, Meriden; New Hampshire, 1959.

30. Howell, D. S., and Elden, H. Unpublished observations. 